\title{
New records of Chironomus Meigen (Diptera, Chironomidae) in the State of São Paulo, Brazil
}

\author{
Leny Célia da Silva Correia ${ }^{1,2} \&$ Susana Trivinho-Strixino ${ }^{1,3}$
}

\begin{abstract}
${ }^{1}$ Departamento de Hidrobiologia, Universidade Federal de São Carlos. Caixa Postal 676, 13565-905 São Carlos-SP, Brasil. 22plenycor@yahoo.com.br

${ }^{3}$ strixino@power.ufscar.br
\end{abstract}

\begin{abstract}
New records of Chironomus Meigen (Diptera, Chironomidae) in the State of São Paulo, Brazil. In this paper seven species of the genus Chironomus Meigen, 1803 are recorded for the first time in the State of São Paulo (Brazil). C. stigmaterus Say, 1823 and C. columbiensis Wülker et al., 1989 are new records for Brazil, while C. calligraphus Goeldi, 1905, C. strenzkei Fittkau, 1968, C. gigas Reiss, 1974, C. latistylus Reiss, 1974 and C. paragigas Reiss, 1974 had already been registered in aquatic systems in North and Northeast regions of Brazil.
\end{abstract}

KEYWORDS. Chironomidae; Chironomus; Diptera; new records.

\begin{abstract}
RESUMO. Novos registros de Chironomus Meigen (Diptera, Chironomidae) no Estado de São Paulo, Brasil. Neste artigo são registradas, pela primeira vez no Estado de São Paulo (Brasil), sete espécies do gênero Chironomus Meigen, 1803. C. stigmaterus Say, 1823 e C. columbiensis Wülker et al., 1989 representam novos registros para o Brasil, enquanto $C$. calligraphus Goeldi, 1905, C. strenzkei Fittkau, 1968, C. gigas Reiss, 1974, C. latistylus Reiss, 1974 e C. paragigas Reiss, 1974 já haviam sido registradas em ambientes aquáticos das regiões norte e nordeste brasileiras.
\end{abstract}

PALAVRAS-CHAVE. Chironomidae; Chironomus; Diptera; novos registros.

The Chironomidae (Diptera) family occurs in all zoogeographical regions of the world and is frequently the most abundant group of insects in fresh or brackish water (Oliver 1971; Pinder 1986; Ashe et al. 1987). The immature stages of some species can live even in extremes of temperature, $\mathrm{pH}$, salinity, depth, current velocity, and productivity. Under certain conditions, such as at low levels of dissolved oxygen, larvae of chironomids may be the only insects present in the benthic sediments.

In spite of the importance of Chironomidae, the taxonomy of the family has remained very confused. Most of the species have been described only from adults and, frequently, the generic concept as applied to adults does not correspond with that for the immature stages. These taxonomic problems arose during the first half of the last century, because the German school (inspired by A. Thienemman) focused mainly on the immature stages while other researchers (notably F. W. Edwards in England, M. Goetghebuer in Belgium and J. J. Kieffer in France) worked almost exclusively with adults. Thus, two taxonomic schemes have been developed simultaneously, with generic limits being frequently much narrower for immatures than for adults. In recent years, some attempts have been carried out to reconcile the two systems (Oliver 1971; Pinder 1983).

The genus Chironomus is one of the oldest recognized genera in the family but, at the species level, it is one of the most confused taxonomically. Many of the species originally described as Chironomus are now assigned not only to different genera but also to different subfamilies. The species descriptions by many early workers were usually very brief and inadequate, sometimes with emphasis placed in characters of little significance that lead to descriptions that may fit several species. In addition, type material of many of these species is now lost, damaged or was not deposited in a museum. There are likely considerably more nomina dubia in the genus Chironomus than valid species (Ashe 1983).

Spies \& Reiss (1996) listed 29 species of Chironomus in the Neotropical region, including 12 categorized as nomina dubia. These authors recognized seven species in Brazil: $C$. atripennis Rempel, 1939, C. calligraphus Goeldi, 1905, C. gigas Reiss, 1974, C. latistylus Reiss, 1974, C. paragigas Reiss, 1974, C. streinzkei Fittkau, 1968 and C. xanthus Rempel, 1939. All the Brazilian species had their immatures and adults stages described, except C. atripennis.

In São Paulo State, two species have been recorded: $C$. brasiliensis Wiedemann, 1828 and C. sancticaroli Strixino \& Strixino, 1981. On the other hand, Spies \& Reiss (op cit.) have evaluated the first as belonging to Axarus Roback, 1980 and proposed that the last one should be placed as a junior synonym of C. xanthus Rempel. Nevertheless, this synonym was not established by the analyses of types.

The presence of Chironomus immatures in lentic and lotic systems of São Paulo State has been pointed out in many studies (Correia \& Trivinho-Strixino 1998; Strixino \& TrivinhoStrixino 1998; Alves \& Strixino 2000; Sonoda \& TrivinhoStrixino 2000; Trivinho-Strixino et al. 2000; Roque \& Trivinho- 
Table I. New Chironomus species (Diptera: Chironomidae) records in São Paulo State, Brazil.

\begin{tabular}{|c|c|c|c|c|}
\hline & Localities & Geographical Coordinates & Specimen Stages & Substrates \\
\hline C. stigmaterus & Stabilization Lagoons & $21^{\circ} 59^{\prime} \mathrm{S}, 47^{\circ} 52^{\prime} \mathrm{W}$ & Adults and Pupae & detritus \\
\hline C. calligraphus & Stabilization Lagoons & $21^{\circ} 59^{\prime} \mathrm{S}, 47^{\circ} 52^{\prime} \mathrm{W}$ & Larvae, Pupae, Adults & detritus \\
\hline \multirow[t]{2}{*}{ C. strenzkei } & Channels of Patos Reservoir & $21^{\circ} 59^{\prime} \mathrm{S}, 47^{\circ} 52^{\prime} \mathrm{W}$ & Larvae, Pupae, Adults & leaf-detritus \\
\hline & Diogo Lake & $21^{\circ} 37^{\prime} \mathrm{S}, 47^{\circ} 48^{\prime} \mathrm{W}$ & Larvae, Pupae, Adults & E. azurea rhizosphere \\
\hline \multirow[t]{5}{*}{ C. gigas } & Beija-Flor Resevoir & $21^{\circ} 36^{\prime} \mathrm{S}, 47^{\circ} 47^{\prime} \mathrm{W}$ & Larvae & sediment \\
\hline & Diogo Lake & $21^{\circ} 37^{\prime} \mathrm{S}, 47^{\circ} 48^{\prime} \mathrm{W}$ & Larvae & sediment \\
\hline & Quilômetro Lake & $21^{\circ} 36^{\prime} \mathrm{S}, 47^{\circ} 49^{\prime} \mathrm{W}$ & Larvae, Pupae, Adults & sediment \\
\hline & Anhumas Stream Resevoir & $21^{\circ} 42^{\prime} \mathrm{S}, 48^{\circ} 00^{\prime} \mathrm{W}$ & Larvae, Adults & sediment \\
\hline & Tietê River & $21^{\circ} 41^{\prime} \mathrm{S}, 51^{\circ} 21^{\prime} \mathrm{W}$ & Adults & \\
\hline \multirow[t]{3}{*}{ C. latistylus } & Quilômetro Lake & $21^{\circ} 36^{\prime} \mathrm{S}, 47^{\circ} 49^{\prime} \mathrm{W}$ & Larvae, Pupae, Adults & sediment \\
\hline & Fazzari Resevoir & $21^{\circ} 58^{\prime} \mathrm{S}, 47^{\circ} 53^{\prime} \mathrm{W}$ & Larvae, Pupae, Adults & woody debris \\
\hline & Beija-Flor Resevoir & $21^{\circ} 36^{\prime} \mathrm{S}, 47^{\circ} 47^{\prime} \mathrm{W}$ & Larvae, Pupae, Adults & woody debris \\
\hline C. paragigas & Fazzari Resevoir & $21^{\circ} 58^{\prime} \mathrm{S}, 47^{\circ} 53^{\prime} \mathrm{W}$ & Larvae, Pupae, Adults & sediment \\
\hline \multirow[t]{3}{*}{ C. columbiensis } & Beija-Flor Resevoir & $21^{\circ} 36^{\prime} \mathrm{S}, 47^{\circ} 47^{\prime} \mathrm{W}$ & Larvae, Pupae, Adults & Eleocharis sp. \\
\hline & Monjolinho Resevoir & $21^{\circ} 59^{\prime} \mathrm{S}, 47^{\circ} 52^{\prime} \mathrm{W}$ & Larvae, Pupae, Adults & Myriophyllum sp. \\
\hline & Channels of Patos Reservoir & $21^{\circ} 59^{\prime} \mathrm{S}, 47^{\circ} 52^{\prime} \mathrm{W}$ & Larvae, Pupae, Adults & leaf-detritus \\
\hline
\end{tabular}

Strixino 2001; Santos \& Henry 2001; Corbi \& Trivinho-Strixino 2002). Nevertheless, species identification was not accomplished in any of the cited researches. Possibly, they have included several species living in different aquatic systems.

Considering the taxonomic problems cited above and the importance of Chironomus immatures in limnological studies, the present work aimed to identify the species inhabiting aquatic systems of São Paulo State with different ecological features.

The study area included lentic and lotic aquatic systems at different localities of Mogi-Guaçu and Tietê hydrographic basins.

The immatures were collected using appropriate equipment to the different aquatic systems and substrates (deep aquatic systems: Ekman dredge in muddy sediments and Van-Veen dredge in sandy sediments; shallow aquatic systems: D-net in sediments, macrophytes and woody debris). Some of the fourth instar larvae were mass reared in plastic containers, others were isolated in small containers in order to obtain reliable life stage associations. Additionally, adult males were collected with light trap equipment and with entomological aspirator. All specimens were preserved in alcohol $70 \%$. Adults were cleared in $10 \%$ potassium hydroxide solution and mounted, with their associated exuviae, using Euparal ${ }^{\circledR}$ as mounting medium. Larvae and pupae were mounted using Hoyer as medium. The specimens were deposited in the Museu de Zoologia da Universidade de São Paulo and in the Reference Collection of Laboratório de Entomologia Aquática da Universidade Federal de São Carlos.

The survey resulted in the identification of 16 species, including 8 new species and 7 new records to the State of São Paulo (Figure 1; Table I). Besides C. sancticaroli Strixino \&
Strixino, 1981, a species previously recorded in the State of São Paulo, we identified the immatures and adults of $C$. stigmaterus Say, 1823, C. calligraphus Goeldi, 1905, C. strenzkei Fittkau, 1968, C. gigas Reiss, 1974, C. latistylus Reiss, 1974, C. paragigas Reiss, 1974, and C. columbiensis Wülker et al., 1989. C. stigmaterus and C. columbiensis are new records for Brazil, while the others have already been collected in other Brazilian States. The new species are currently being described.

The immatures of C. stigmaterus and C. calligraphus were found only in the detritus deposited in shallow waste stabilization lagoons of a chicken slaughter-house (Table I). Chironomus stigmaterus has already been collected in United States of America and Mexico, often in sewage oxidation ponds and windmill tanks. Grodhaus (1967) has sampled $C$. stigmaterus in waste stabilization lagoons at nine localities of California (USA). C. calligraphus has already been sampled in small and eutrophic lentic environments as pools and reservoirs in Belém (Pará, Brazil), shallow puddle in Paraná da Terra Nova (Amazonas, Brazil), fish pond in Cuiabá (Mato Grosso, Brazil), a turtle-inhabited garden pool in San Fernando (Cali, Colombia) and sewage treatment plants and temporary waters in Lima (Peru) (Fittkau 1965; Spies et al. 2002). In Southern United States of America (California, New Mexico, Texas and Florida), the immatures of this species have been found in small and temporary waters. In California (USA), specimens were predominantly collected in temporarily lotic habitats (surface speeds measuring less than $0.5 \mathrm{~m} / \mathrm{s}$ ) of flood control channels, creeks and rivers (Spies et al. op cit.).

C. gigas, C. latistylus and C. paragigas were collected only in aquatic systems with low anthropic influence (Table I). C. gigas was collected on sediments of two ox-bow lakes (Quilômetro Lake and Diogo Lake) and Beija-Flor Reservoir 


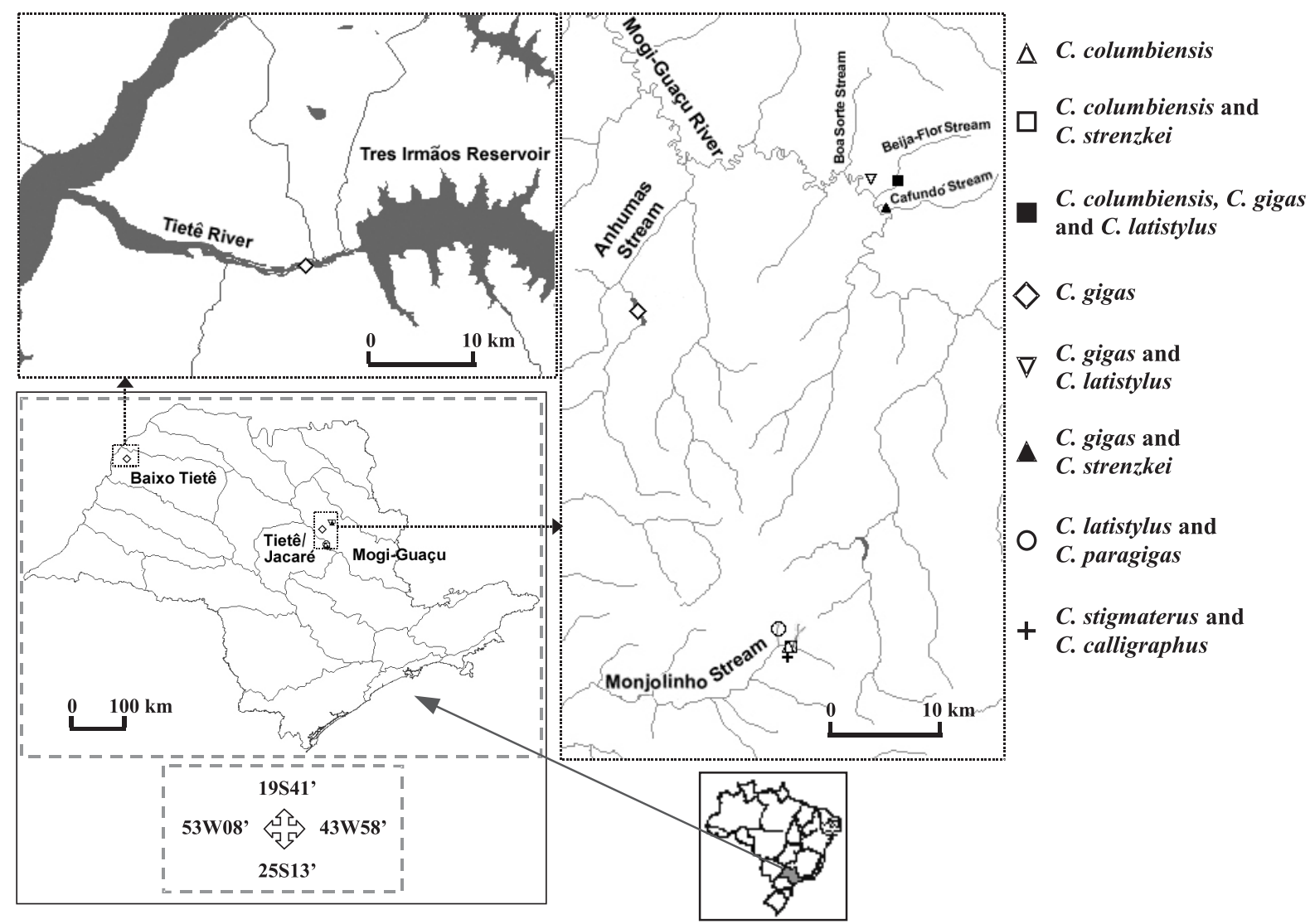

Fig. 1. Map of São Paulo State (Brazil) indicating the localities of the new Chironomus species (Diptera: Chironomidae) records (modified from http://sinbiota.cria.org.br/atlas).

(Jataí Ecological Station, Luiz Antônio- SP), on the sediment of Anhumas Stream Reservoir (Náutico Club, Américo Brasiliense- SP) and in Tietê River dowstream of Três Irmãos Reservoir (Itapura, São Paulo). This species has already been sampled in Central Amazonian white water lakes (Passarinhos Lake and Muratu Lake) and mixed water lakes with predominance of white water (Jacaretinga Lake), located near Manaus in the Solimões River watershed. In addition, their adults have been sampled in Meta River (Mozambique, Colômbia) (Reiss 1974).

C. latistylus immatures were sampled on the sediment of Quilômetro Lake and on woody debris (branches) of BeijaFlor Reservoir (Jataí Ecological Station- Luiz Antônio) and Fazzari Reservoir (UFSCar- São Carlos). Reiss (op cit.) found C. latistylus in a wide range of Central Amazonian inundation forests. The immatures were sampled in inundation forests of Tarumã Mirim (Negro River), in Janauari Lake (Solimões River) and in Cabaliana Lake. The adults were collected near Cuieiras River (Negro River), Cururu River (Rio Tapajós tributary) and Branco River (delta of Igarapé do Curubaú). In addition, this species was found in Meta River, in Mozambique (Colombia) and in the drainage area of the Orinoco River.

C. paragigas was sampled on the sediments of Fazzari Reservoir, located at Universidade Federal de São Carlos
(UFSCar- São Carlos). In Amazônia, their larvae occur in the black water of igapó of the lower Tarumã-Mirim River and at the margins of Tupé Lake (Negro River). Reiss (op cit.) verified a larger range of $C$. paragigas distribution through the collection of adults near Paraná do Careiro River, Cabaliana Lake, Branquinho River, Gigante Waterfall (Ducke Reserve), Branco River (delta of Igarapé do Curubaú, Roraima) and Madeira River.

C. columbiensis immatures were sampled on macrophyte stands in Beija-Flor Reservoir (Jataí Ecological Station- Luiz Antônio) and in Monjolinho Reservoir (UFSCar- São Carlos) and on leaf-detritus beds in water discharge drainage channels of Patos Reservoir (São Carlos Ecological Park- São Carlos) (Table I). In Beija-Flor Reservoir, the immatures were associated with Eleocharis sp., a macrophyte the large stands of which cover the bottom. In Monjolinho Reservoir, larvae were sampled in the periphyton of Myriophyllum sp. leaves, a macrophyte present in the upstream reach of the reservoir. $C$. columbiensis has already been registered in San Fernando (Cali, Colômbia) and in Jocotan (Chiquimula, Guatemala). In San Fernando, their larvae were collected from the algal layer on the walls of a turtle-inhabited garden pool. In Jocotan, the immatures occurred in rainwater tanks (Wülker et al. 1989).

C. strenzkei was collected on leaf-detritus beds in water 
discharge drainage channels of Patos Reservoir and on the rhizosphere of Eichhornia azurea (Swartz) Kunth, 1788 in Diogo Lake (Table I). The types of $C$. strenzkei were collected in mud and algae accumulating in the bilge water of dugout canoes located in the region of Rio Negro in Manaus (Amazônia, Brazil) (Fittkau 1968). This species was also recorded in eutrophic aquatic systems of the Neartic region, in Hyperion wastewater treatment plant in El Segundo (Los Angeles, California- USA). It is likely that C. strenzkei has been introduced in southern California recently and has the potential to survive throughout the southern USA and other lower temperate and subtropical areas (Sublette \& Mulla 2000).

Although this study was concentrated in some regions of São Paulo State, the results provide new information about the distribution of Chironomus species in different biotopes. In addition, the survey showed a larger distribution of $C$. stigmaterus and C. columbiensis in the American Continent as well as of $C$. calligraphus, $C$. gigas, $C$. latistylus, $C$. paragigas and C. strenzkei in Brazil.

Acknowledgements. The first author received a grant from FAPESP (00/01548-0) within the BIOTA/FAPESP - The Biodiversity Virtual Institute Program (www.biota.org.br). The authors thank all colleagues who collaborated during the field and laboratory work.

\section{REFERENCES}

Alves, R. G. \& G. Strixino. 2000. Influência da variação do nível da água sobre a comunidade macrobentônica da Lagoa do Diogo (Luiz Antônio, SP), p.733-742. In: J. E. Santos \& J. S. R. Pires (eds.). Estação Ecológica de Jataí: estudos integrados em ecossistemas. São Carlos: Rima. 867 p.

Ashe, P. 1983. A catalogue of chironomid genera and subgenera of the world including synonyms (Diptera: Chironomidae). Entomologica scandinavica Supplement 17: 3-68.

Ashe, P.; D. A. Murray \& F. Reiss. 1987. The zoogeographical distribution of Chironomidae (Insecta: Diptera). Annals of Limnology 23: 27-60.

Corbi, J. J. \& S. Trivinho-Strixino. 2002. Spatial and bathymetric distribution of the macrobenthic fauna of the Ribeirão das Anhumas reservoir (Américo Brasiliense-SP, Brasil). Acta Limnologica Brasiliensia 14: $35-42$.

Correia, L. C. S. \& S. Trivinho-Strixino.1998. Macroinvertebrados da rizosfera de Scirpus cubensis na Lagoa do Infernão (Estação Ecológica de Jataí, SP): estrutura e função. Acta Limnologica Brasiliensia 10: $37-47$.

Fittkau, E. J. 1965. Revision der von E. Goeldi aus dem Amazonasgebiet beschriebenen Chironomiden (Diptera). Chironomiden studien X. Beitr Neotropical Fauna 4: 209-226.

Fittkau, E. J. 1968. Chironomus streinzkei n. sp. (Chironomidae, Dipt.), ein neues Laboratoriumstier. Zeitschtift für Morphologie der Tiere 63: 239-250.

Grodhaus, G. 1967. Identification of Chironomid midges commonly associated with waste stabilization lagoons in California. California Vector Views 14: 1-12.

Oliver, D. R. 1971. Life History of the Chironomidae. Annual Review of Entomology 16: 211-230.

Pinder, L. C. V. 1983. The larvae of Chironomidae (Diptera) of the Holartic region- introduction, p. 7-10. In: T. Wiederholm (ed.). Chironomidae of the Holartic region: Keys and diagnoses. Part 1. Larvae. Entomologica scandinavica Supplement, v.19. $457 \mathrm{p}$.

Pinder, L. C. V. 1986. Biology of freshwater Chironomidae. Annual Review of Entomology 31: 1-23.

Reiss, F. 1974. Vier neue Chironomus-Arten (Chironomidae, Diptera) und ihre ökologische Bedeutung für die Benthosfauna zentralamazonischer Seen und Überschwemmungswälder. Amazoniana 5: 3-23.

Roque, F. O. \& S. Trivinho-Strixino. 2001. Benthic macroinvertebrates in mesohabitats of different spatial dimensions in a first order stream (São Carlos - SP). Acta Limnologica Brasiliensia 13: 69-77.

Santos, C. M. \& R. Henry. 2001. Composição, distribuição e abundância de Chironomidae (Diptera- Insecta) na Represa de Jurumirim (Rio Paranapanema- SP). Acta Limnologica Brasiliensia 23: 99115.

Sonoda, K. C. \& S. Trivinho-Strixino. 2000. Dinâmica de emergência de Chironomidae (Diptera) da fitofauna de Cabomba piauhyensis Gardney, 1844, na Lagoa do Infernão (Estação Ecológica de Jataí, Luiz Antônio, SP), p. 743-754. In: J. E. Santos \& J. S. R. Pires (eds.). Estação Ecológica de Jataí: estudos integrados em ecossistemas. São Carlos: Rima. 867 p.

Spies, M. \& F. Reiss. 1996. Catalog and bibliography of Neotropical and Mexican Chironomidae (Insecta, Diptera). Spixiana Supplement 22: 61-119.

Spies, M.; J. E. Sublette; M. F. Sublette; W. F. Wülker; J. Martin; A. Hille; M. A. Miller \& K. Witt. 2002. Pan-American Chironomus calligraphus Goeldi, 1905 (Diptera, Chironomidae): Species or Complex? Evidence from External Morphology, Karyology and DNA Sequencing. Aquatic Insects 24: 91-113.

Strixino, G. \& S. Trivinho-Strixino. 1998. Povoamentos de Chironomidae (Diptera) em lagos artificiais, p. 141-154. In: J. L. Nessimian \& A. L. Carvalho (eds.). Ecologia de Insetos Aquáticos. Series Oecologia Braziliensis Vol. V. Rio de Janeiro, PPGUFRJ, xvii+309 p.

Sublette, J. E. \& M. S. Mulla. 2000. Chironomus strenzkei Fittkau - a new Pan-American distribution, with a review of a recent similar addition to the Neartic midges (Insecta, Diptera, Chironomidae). Spixiana 23: $145-149$.

Trivinho-Strixino, S.; L. C. S. Correia \& K. Sonoda. 2000. Phytophilous Chironomidae (Diptera) and other macroinvertebrates in the oxbow Infernão Lake (Jataí Ecological Station, Luiz Antônio, SP, Brazil). Revista Brasileira de Biologia 60: 527-535.

Wülker, W.; J. E. Sublette; E. Morath \& J. Martin. 1989. Chironomus columbiensis $\mathrm{n}$. sp. in South America and Chironomus anonymus Williston in North America - closely related species. Studies on Neotropical Fauna and Environment 24: 121-136. 